\title{
Sulfate Ions Removal from an Aqueous Solution Modeled on an Abandoned Mine by Electrocoagulation Process with Recirculation
}

\author{
Miguel A. Sandoval ${ }^{1}$, José L. Nava ${ }^{2}$, Oscar Coreño ${ }^{3}$, Gilberto Carreño $^{2, *}$, Luz A. Arias ${ }^{2}$, \\ Dellanira Méndez ${ }^{4}$ \\ ${ }^{1}$ Universidad de Guanajuato, Departamento de Ingeniería Química, Norial Alta S/N, 36050 \\ Guanajuato, Guanajuato, México \\ ${ }^{2}$ Universidad de Guanajuato, Departamento de Ingeniería Geomática e Hidráulica, Av. Juárez 77 , \\ Zona Centro, 36000 Guanajuato, Guanajuato, México \\ ${ }^{3}$ Universidad de Guanajuato, Departamento de Ingeniería Civil, Av. Juárez 77, Zona Centro, 36000 \\ Guanajuato, Guanajuato, México \\ ${ }^{4}$ Universidad Politécnica del Bicentenario, Departamento de Ingeniería en Agrotecnología, 36283 San \\ Juan de los Durán, Silao, Guanajuato, México \\ *E-mail: gca@ugto.mx
}

doi: $10.20964 / 2017.02 .08$

Received: 21 October 2016 / Accepted: 24 November 2016 / Published: 30 December 2016

This paper shows the feasibility of sulfate ions removal by electrocoagulation (EC) with recirculation, which includes flocculation and clarification stages. The electrocoagulation stage uses aluminum as a sacrificial anode in a continuous filter-press reactor. Sulfate removal from synthetic water with chemistry modeled on an abandoned mine $\left(3500 \mathrm{mg} \mathrm{L}^{-1} \mathrm{SO}_{4}^{2-}\right.$, in $1.5 \mathrm{mg} \mathrm{L}^{-1} \mathrm{NaClO}$ at $\mathrm{pH}=6.77$ and conductivity $6.56 \mathrm{mS} \mathrm{cm}{ }^{-1}$ ) was tested. This solution resembles water from abandoned mines in Guanajuato City, Mexico. We analyzed the influence of current density $(j)$ and linear flow velocity in the electrocoagulation reactor $\left(u_{r}\right)$ on the sulfate removal efficiency. The EC tests were carried out at $0.91 \leq u_{r} \leq 3.64 \mathrm{~cm} \mathrm{~s}^{-1}$ and $4 \leq j \leq 6 \mathrm{~mA} \mathrm{~cm}^{-2}$. The first configuration (single EC process) did not meet the Mexican standard limit for sulfate $\left(\mathrm{SO}_{4}^{2-} \leq 400 \mathrm{mg} \mathrm{L}^{-1}\right)$, due to the produced floc being saturated by an excess of sulfate ions. The second EC (two recycles of the EC process) satisfied the Mexican standard after the second recirculation, with a residual sulfate concentration of $\mathrm{SO}_{4}^{2-}=270 \mathrm{mg} \mathrm{L}^{-1}$, obtained at $u_{r}=0.91 \mathrm{~cm} \mathrm{~s}^{-1}$ and $j=6 \mathrm{~mA} \mathrm{~cm}{ }^{-2}$, giving a theoretical aluminum dose of $C_{A l^{3+}}=149.34$ $\mathrm{mg} \mathrm{L}^{-1}$. SEM, EDA-X analyses were performed to confirm the presence of sulfate ions in the flocs. XRD patterns confirm the presence of an aluminum hydroxide (Boehmite) that causes the sulfate removal via sulfate adsorption on the aluminum flocs. The flocs (sodium sulfate-aluminum hydroxide) presented sizes below $2 \mu \mathrm{m}$. 
Keywords: Electrocoagulation, Sulfate removal, Filter press reactor, Abandoned mine water, Aluminum sacrificial anode.

\section{FULL TEXT}

(C) 2017 The Authors. Published by ESG (www.electrochemsci.org). This article is an open access article distributed under the terms and conditions of the Creative Commons Attribution license (http://creativecommons.org/licenses/by/4.0/). 